\title{
Assembling value for money in the UK Department for International Development
}

\section{Document Version}

Accepted author manuscript

Link to publication record in Manchester Research Explorer

\section{Citation for published version (APA):}

Fredriksen, A. (2018). Assembling value for money in the UK Department for International Development. In S. Bracking, A. Fredriksen, S. Sullivan, \& P. Woodhouse (Eds.), Valuing Development, Environment and Conservation: Creating Values That Matter Routledge.

\section{Published in:}

Valuing Development, Environment and Conservation

\section{Citing this paper}

Please note that where the full-text provided on Manchester Research Explorer is the Author Accepted Manuscript or Proof version this may differ from the final Published version. If citing, it is advised that you check and use the publisher's definitive version.

\section{General rights}

Copyright and moral rights for the publications made accessible in the Research Explorer are retained by the authors and/or other copyright owners and it is a condition of accessing publications that users recognise and abide by the legal requirements associated with these rights.

\section{Takedown policy}

If you believe that this document breaches copyright please refer to the University of Manchester's Takedown Procedures [http://man.ac.uk/04Y6Bo] or contact uml.scholarlycommunications@manchester.ac.uk providing relevant details, so we can investigate your claim.

\section{OPEN ACCESS}


Fredriksen, Aurora (2018) "Assembling value for money in the UK

Department for International Development” pp. 45-58 in Sarah Bracking, Aurora Fredriksen, Sian Sullivan and Phil Woodhouse (eds.) Valuing

Development, Environment and Conservation: Creating Values that Matter. London: Routledge.

\title{
Pre-proof author-created pdf
}

\begin{abstract}
In recent decades, international development agencies have become increasingly focused on demonstrating the effectiveness and impact of their work through practices of (e)valuation and assessment at the level of individual projects or programmes. This chapter examines one iteration of such 'aid effectiveness' accounting, namely 'value for money' (VFM), which, at the time of writing, must be demonstrated for each project or programme funded by the UK government's DfID. Drawing on insights from assemblage theory and the performative economics literature, this chapter traces how VFM is variously calculated in practice and explores two related framings that circumscribe the possibilities of these VFM calculations. The first framing equates robust evidence with quantitative evidence. The second figures a linear relationship between development inputs and results. The chapter shows how the calculations of VFM within these framings performatively express the value of international development as a quantified, economic relationship between development inputs and results. The analysis is situated within the particular socio-political context in which this performance of VFM by DfID has been mobilised to defend development aid spending from its critics and considers the wider relevance of this dynamic.
\end{abstract}




\section{Introduction}

In 2010 the UK's newly elected coalition government began enacting a wide-ranging programme of austerity, involving drastic budget cuts across all government departments except the National Health Service (NHS) and the Department for International Development (DfID). While sparing the NHS from financial cuts was widely popular, the ring-fencing of DfID's budget was less so. This decision drew negative attention amid press allegations that DfID was wasting taxpayers' money on excessive overhead costs (e.g. Boin 2010; Dixon 2010) and surveys showing a decline in public support for foreign aid (TNS UK 2010). In this context, the contemporaneous mandate that all government departments demonstrate 'value for money' for all spending gained particular traction at DfID, where it became, according to one policy consultant "a sort of mantra" for defending continued spending on international aid at a time of domestic austerity. At the same time that demonstrating 'value for money' became a means of justifying the worth of spending taxpayers' money on international development, it also drew criticism from those who worried that its requirement to show measurable results would discourage certain types of aid and replace (or obscure) difficult political and moral decisions with technocratic procedure (e.g. Leroy 2011; Scott et al. 2012). Taking this concern seriously, in this chapter I look at how value for money is calculated and framed in practice, and how these practices perform the value of international development programming in particular ways, to the exclusion of alternatives.

It should be noted that, while this chapter takes UK DfID as a site for exploring the demonstration of value for money (hereafter VfM) in development aid, the use of VfM calculations in development assessments and evaluations is by no means unique to DfID or the UK. Indeed, demonstrating the VfM of development aid is now common to several large donors (Bond 2011; Davis 2012). Consequently, while this chapter draws its empirical material from interviews and documentary reviews centred on VfM at UK DfID, it also speaks to wider issues around VfM as a measure of worth in international development aid more generally. The chapter begins by briefly situating VfM within the larger institutional setting of development aid in the post-Second World War era and in particular, the rise of the aid effectiveness agenda from the 1990s onwards. This is followed by an examination of both the calculation and the framing of VfM at DfID. An analysis of the performative effects of these practices supports the conclusion that VfM does not simply capture an objective measure of development value, but instead performatively shapes what counts as development value in the first place. A concluding section returns to the concern introduced above, reflecting on the potential for technocratic justifications like VfM to displace moral and political engagements, debate and justifications for development decisions.

\section{Situating value for money}

As with other fields of policy and practice (see Chapters 1 and 2, this volume), in international development the generation, assessment and enactment of various registers of value - e.g. economic, political, moral - have never been easily disentangled from one another (though neither have they been coterminous). At least since its modern inception 
following the Second World War, international development aid has emphasised economic value, largely understood in the $20^{\text {th }}$ century in terms of macro-economic growth as measured by gross domestic product (GDP). At the same time, development aid has consistently been concerned with generating non-economic value(s), most notably geo-political value(s), but also moral or charitable value(s) and, more recently, social and rights-based value(s). ${ }^{2}$ While arriving relatively recently on the international development scene, VfM is part of a broader shift in the locus of value assessment in international aid, commencing with the post-cold war rise of the related agendas of 'aid effectiveness', 'aid accountability', and 'new public management'.

The rise of aid effectiveness and accountability doctrines from the 1990s onward has had a major impact on how the value of international development aid is understood, measured, and projected. In response to the widespread failure of international development aid to lift countries out of poverty and generate sustained economic growth in the post-war decades, aid effectiveness - codified in the 2005 Paris Declaration on Aid Effectiveness - seeks to "improve the quality of aid and its impact on development" (OECD 2017), by deploying better assessment, monitoring, and evaluation techniques to make it (literally) more accountable. Thus the aid effectiveness agenda has had the practical consequence of replacing the broad and largely non-specific macro-goals of earlier regimes of international development, with a regime of specific accountability for results at the level of individual programmes and projects (Krause 2014). One outcome is that aid effectiveness, as a project to make aid more accountable, has in practice made different aid projects and programmes more comparable through practices that frame projects in certain standardised ways. Aid effectiveness standardises the requirement for projects and programmes across the board to be explicit about their goals, how these will be achieved, and how evidence of the effectiveness of the proposed project or programme will be demonstrated.

As well as this narrowing of the locus of development value (from the macro-economy to the project), the requirement that aid effectiveness show measurable results has had at least two notable unintended consequences. Firstly, this makes broadly ambitious, innovative or idealistic programmes and projects more difficult to implement (e.g. Mosse 2004; 2011). Secondly (reinforcing the first), it has brought about what Krause (2014) describes as a process of 'quasi-marketization' (cf. Çalışkan and Callon 2010) in which consultancies and NGOs compete for contracts from donors in a market where the beneficiaries of aid stand in as quasi-commodities. With its emphasis on cost savings, competition and establishing a framework for comparing different projects and programmes, VfM extends and deepens the quasi-marketisation of development aid and its beneficiaries. I expand on this point below through examination of the calculation, framing and performativity of VfM. Firstly, however, it is useful to define more specifically what DfID means by the phrase 'value for money'. 


\section{Defining value for money}

The UK National Accounting Office defines VfM as "the optimal use of resources to achieve intended outcomes". Building from this official definition, DfID has declared that, for them, VfM means "maximiz[ing] the impact of each pound spent to improve poor people's lives" (DfID 2011, 3). Moreover, DfID’s ‘Common Agenda for Development Results' (DfID 2011) calls for a reorientation of its development policies (and those of its partners) that not only highlights results and VfM, but puts these 'at the heart' of everything it does. The treatment of VfM in these statements speaks to the 'mantra'-like status that VfM holds for DfID noted above. VfM became a way of defending the sparing of DfID's budget from austerity-driven funding cuts, for "saying ok, well we're committed internationally to raising the aid budget to $0.7 \%$ of GDP, but in doing this we will make sure that ... every pound spent on aid will get the maximum amount of impact" (Interview 04/07/15). DfID is quick to note, however, that attaining good VfM is not about going with the cheapest options, but going for the most efficient ones, i.e. the cheapest option that still results in the desired outcomes. Thus VfM also speaks to a renewed emphasis on 'evidence-based' decision-making in international development. This is indicated for example, in statements from the Common Agenda report such as these:

"To maximise the impact of UK aid we need to be very clear about the results (outputs and outcomes) we expect to achieve as well as the costs." (DfID 2011,3)

"For VfM agenda to succeed we all need to show diligence in what we decide to do and how we implement (knowing what works and being sure that we are delivering development results in the most effective and efficient way)." (DfID 2011, 12)

These accounts, and moreover the idea of evidence-based decision-making in general assume that it is possible to widely evidence 'what works' in the first place. Leaving aside this questionable assumption, the remainder of this chapter traces the processes of doing VfM, examining how VfM is calculated, framed, and performed.

\section{Calculating value for money}

There is no standard or prescriptive way of calculating VfM. Indeed, VfM is not itself a calculative device; it's not a formula or accounting tool, but rather a way of framing and performing value as a relationship between inputs and outputs or outcomes (e.g. Jackson 2012). Guidance notes produced by consultants contracted by DfID have varied by author and sector in the methods they use or recommend for calculating VfM. The most commonly used techniques for assessing VfM within aid agencies include: cost-benefit analysis (CBA), cost-effectiveness analysis (CEA), social-return on investment (SROI), and basic efficiency resource analysis (BER) (for an overview of each of these methods see Davis 2012). However, assessment techniques that are less familiar to the aid community such as 
Randomised Control Trials (RCTs) and community scoring have also been suggested (ICAI 2011; various interviews).

The method used to calculate VfM is thus flexible, more a matter of reaching an agreement between the donor and the consultant or delivery partner (though often to the notable exclusion of beneficiaries). Take, for example, descriptions of the process of deciding how to measure VfM from two different development consultants:

“You submit your proposal, there's an evaluation, and quite often there's a preferred bidder at that point ... then negotiations start in terms of, you've submitted this as your value for money approach, now we need to firm up on that, can you firm up on the criteria? How are you going to deliver value for money and enhanced value for money, you know, what's above and beyond what you've stated there that could be used in scale-up. So, it's an ongoing discussion, but it's a bit one-way in terms of they're expecting - quite rightly to a certain extent - the consultant to come up with ways on the programme that real value for money could be enhanced and added going forward." (Interview 22/10/15).

"The DfID staff member was concerned that we had sort of cut and dried guidance on what to measure, or metrics as he called them, everything had to be metrics for this and that." (Interview 04/07/15).

As these two accounts show, consultants are hired by large donors like DfID to come up with ways of assessing or demonstrating the VfM of different programmes or projects, and while donors will accept a wide variety of techniques, they want these to be clearly laid out and robustly justified in the consultant's report. In practice, this often comes down to a desire for quantitative measures based on an assumption (often, but not always, unspoken) that quantification equals robustness.

The institutional push to quantify outcomes - to have metrics for every development result has unsurprisingly led to concerns that less quantifiable outputs or impacts might be sidelined in favour of more easily counted ones (e.g. Vardakoulias 2013). Consider, for example, the following scenario recounted by one interviewee:

"Let's say you're building six more classrooms and the result of those six more classrooms is six times 30 kids attend so you've got 180 extra kids every year attending that school; that's straightforward, you know that's very easy. But when you're talking about how the welfare and wellbeing and the economic situation in a district has improved as a result of access being opened up [from building a new road], that's much more difficult. That's part of the issue in terms of measurement: it's not easy to measure some things. " (Interview, 22/10/15) 
Certain results (e.g. school attendance), can be easily quantified in VfM calculations, while others (e.g. wellbeing), cannot.

DfID's official line is that the difficulty of quantifying some types of outcomes or impacts should not be a hindrance to including them in VfM assessments. As stated in the Common Agenda: "It's very hard to quantify some benefits e.g. what is the value of a free and fair election? But demonstrating results and tackling difficult development issues are not alternatives - we need to do both" (DfID 2011, 6). In other words, consultants and service providers will need to work even harder to develop new ways of measuring and quantifying those more 'difficult-to-quantify' results. Notice then how quantifying benefits and demonstrating results are equated in the call to rise to the challenge of demonstrating (i.e. quantifying) the benefits of aid for addressing 'difficult development issues'.

This likening of quantification with 'evidence' is not unique to DfID, but widespread throughout international development and governance institutions, where reliance on statistics in general and indicators in particular is paramount (see Davis et al. 2010; Fredriksen 2012; Hansen and Porter 2012; Merry 2011). The appeal of quantification comes from the capacity of quantified data "to convert complicated contextually variable phenomena into unambiguous, clear and impersonal measures" (Merry 2011, S84), depicting them as transparent, non-interpretive - and therefore apolitical - facts (Porter 1995; Poovey 1998). By assuming the appearance of neutral fact, quantified representations of VfM allow policy-makers and desk officers at DfID to decide between diverse projects and programming in a way that seems fair, rational, and non-political, a feature that is common to other larger donors too.

In parallel, the process of producing quantified evidence of results is, in practice, always messier and more interpretive than its final numerical representation would suggest. Turning results into numbers to plug into $\mathrm{CBA}, \mathrm{CBE}$, SROI or other equations for calculating VfM, inevitably involves subjective judgements, negotiations and even 'gut feelings' on the part of the consultants, service providers and desk officers involved. As with other types of calculation, the process of calculating VfM might be better described as one of 'qualculation' (Cochoy 2008), in which quantitative calculation is informed by qualitative judgements. This is reflected in the account of one consultant who described his involvement in developing VfM guidance in terms of an opening up of the concept to include qualitative judgements:

"It's not that I'm terrifically interested in doing endless appraisals or cost-benefit analyses. I'm quite sceptical of the whole idea actually. But for me it's been a route for being involved in [development] programmes and trying to make sure that the interpretation of value for money is sufficiently broad. See, one of the problems ... is that it tends to be reduced to a few sort of standard formulae in DfID value for money work and not interpreted in a sufficiently broad fashion." (Interview 04/07/15) 
Another consultant emphasised the role of expert judgement and 'gut feeling' in VfM calculations, explaining:

"As consultants we kind of work on evidence and gut feeling and relationships with stakeholders and you get a much better, sort of more rounded view. And some of the evidence [DfID are] looking for has to be for clear tangible evidence, whereas some of it is actually more relationships and understanding of stakeholder drivers, influences and those types of things." (Interview 22/10/15)

Undeniably, some official guidance on calculating VfM notes that translating qualitative realities into quantified measures will require assessors to make judgement calls; as one such report states, calculating VfM "will invariably involve large doses of art and subjective judgement" (ICAI 2011,3).

The judgements and 'gut feelings' underlying the assessment of VfM (and indeed many other development assessments and evaluations) appear in official documents as stated assumptions. As with other fields where quantified accounting practices dominate, it is standard to make assumptions explicit when translating perceived development results into quantified development outcomes as a way of accounting for judgement. Thus using 'gut feeling and relationships' is acceptable in demonstrating VfM, so long as you "demonstrate how you got to that, which is then questionable of course" (Interview 22/10/15). In other words, the use of subjective judgements in VfM calculations is negotiated between desk officers at DfID and consultants or service providers. The following contractor's experience with project proposals speaks to this:

"I think quite often there's enough evidence to be able to make the move on [demonstrating the VfM of a project], but DfID may insist that, no it's not sufficiently evidence-based, it's not robust enough, it could be questioned, it could be whatever. And we do see that at times depending on different advisors. " (Interview 22/10/15)

So, while VfM is "not the hard and rigorous process that the political rhetoric around it may suggest" (ICAI 2011, 3), there are limits to the use of personal judgements in quantifying VfM. DfID staff tend to be less comfortable when VfM assessments rely on 'too many' assumptions or when assumptions are based on personal experience and/or gut feelings alone. Assumptions are acceptable, but are best couched in 'evidence' from previous evaluations or accepted indicators. In other words, they should have some quantitative content, regardless of whether such content involved a high degree of expert judgement and negotiation (see Merry 2011). Again, we see 'quantitative' equated with 'robust' in the demonstration of VfM.

Calculating VfM, as this section has shown, is a process involving a variety of calculative techniques (CBA, CBE, SROI, BER etc.), all of which involve at least some expert 
judgement and 'qualculations' in the translation of qualitatively messy situations into quantities of development outcomes. While they rely on a wide range of methods, all of these techniques have one thing in common: they aim to produce commensurable values for very different projects and programmes. The use of assumptions (preferably based on some preexisting standards) allows the non-quantifiable particularities of situations to be framed out of VfM assessments, making them commensurable across different projects, places and timeframes. The cost is that such quantified results (and their relationship to demonstrating the VfM of a development project or programme), may exclude important aspects of a particular context, giving only a partial picture of an intervention's efficacy, or lack thereof. The process of quantification is however, not the only way in which different projects and programmes are made commensurable through VfM assessments. In the following section, I look at the framing of VfM as a linear relationship expressible through the 'logframe' approach.

\section{Framing value for money}

Once the incommensurable qualitative realities of a project or programme have been translated into commensurable quantities of development outcomes as described above, they can be used to create a logframe (i.e. a logical framework matrix, a standard planning tool for showing how project inputs will translate into results, or outcomes). Among other things (see Krause 2014 on the history and use of logframes), the use of logframes figures a linear relationship between project inputs and development outcomes and impacts. In the case of VfM, projects are encouraged to use a modified logframe based on the '3Es' (see Figure 3.1). The 3Es logframe shows a clear linear movement from inputs to process to three successive levels of results: outputs, outcomes and impact. Inputs can be easily costed, and thus account for the first ' $\mathrm{E}$ ' - economy. The second ' $\mathrm{E}$ ' accounts for how efficiently inputs are translated to outputs, while the third ' $\mathrm{E}$ ' - effectiveness, accounts for how well outputs engender the desired outcomes. An arrow leading from inputs (economy) to impact represents 'costeffectiveness', while a 'fourth E' - equity, is depicted as operating from the start to the finish of the chain. It is notable however, that the framework continues to foreground the '3Es', thereby relegating this fourth $\mathrm{E}$ to a sort of afterthought.

The 3Es framework for framing VfM is based on DfID's more general logframe template, with its standard 'results chain' terminology (which replaces the terms 'goal' and 'purpose' common in other logframe schemas with 'impact' and 'outcome'). Of course, the very language of a 'results chain' implies linearity, conveying the sense of a chain moving from one link to the next. More broadly, the logframe model posits a clear progression from inputs to outputs and impacts in which project planners can clearly link inputs to results in a straightforward manner. Any evidence and assumptions used to support the claims made by the logframe must be clearly stated up front (see above) and adaptation of the model as the project unfolds is limited. Talking to this point, a development consultant for DfID explained:

\footnotetext{
"Whilst they [DfID] ask for value for money, they don't want to change too much. And part of that is linked to the milestone payments - payment by results - because they're all
} 
measured against the logframe which have clear and tangible outputs. And if you start to adapt the programme because you see opportunities elsewhere, you move away from that logframe, so it's difficult then for them to measure and demonstrate the performance of the programme, despite the fact it could actually have much greater impact as a result of that." (Interview 22/10/15)

Moving away from the logframe by adapting projects as they develop disrupts its linearity, hampering the ability to measure eventual impacts against initial inputs in the way the logframe requires.

Figure 3.1: DfID's '3Es' Framework for VfM

Source: DfID $(2011 \mathrm{a}, 4)$

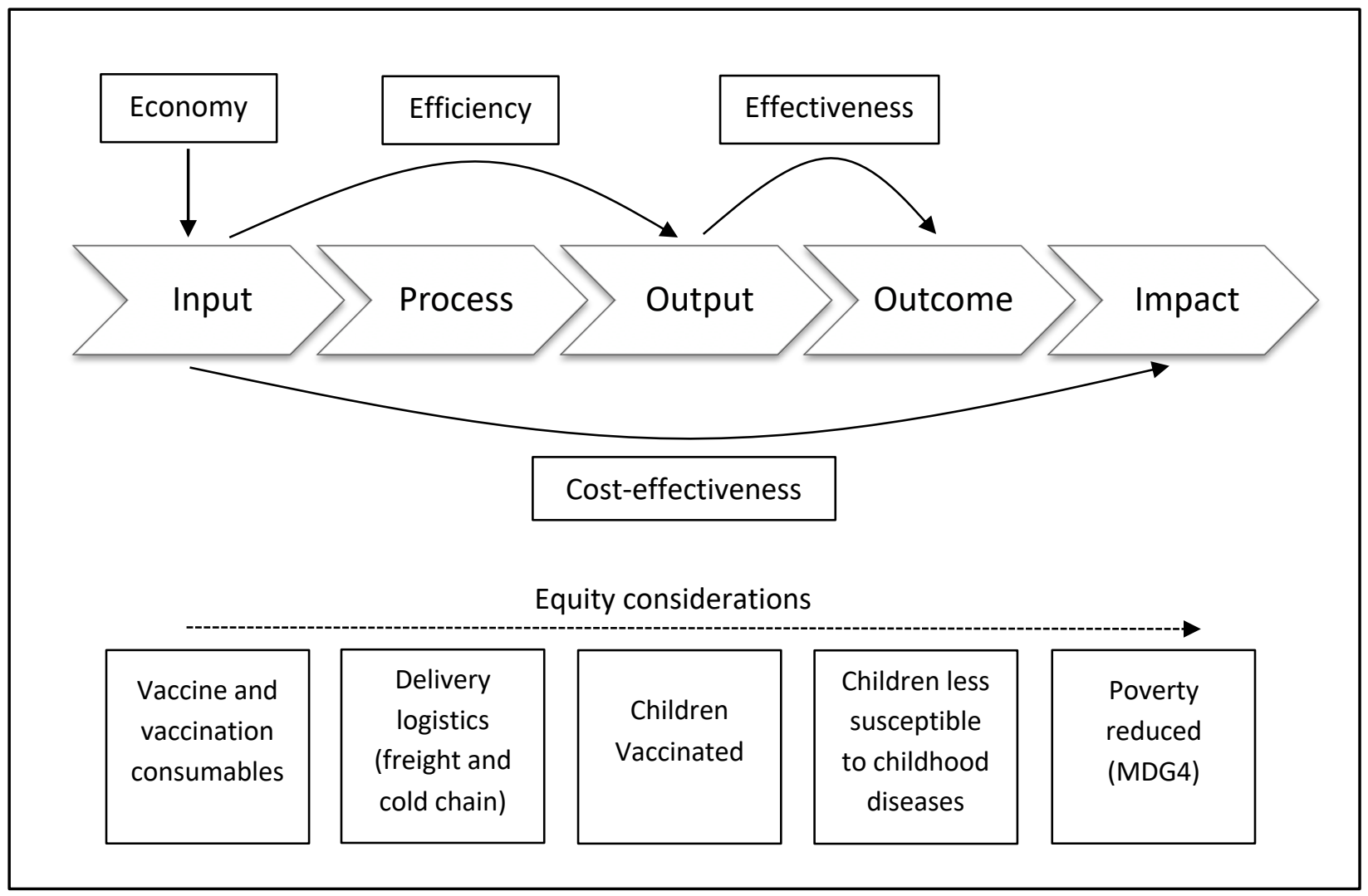

In the same way that quantification can mask the details of specific contexts, the linearity of DfID's 3Es logframe for VFM obscures the more complicated, non-linear, relationships that often exist on the ground. Even when a desired impact (e.g. economic growth) is in itself relatively easy to measure, the extent to which the inputs of a specific project or programme contributed to this larger impact is often unknown. In the above example of opening up access, the inputs were roads. While there is reasonable evidence that opening up access to remote locations will contribute to economic growth, it is impossible to know how much this 
specific input - roads (or even its associated outcome - opened up access) - contributed to the larger impact of economic growth. This after all, is likely to be affected by a wealth of non-linear, entangled relationships involving anything from local weather conditions to distant stock markets. Moreover, economic growth is unlikely to be evenly distributed across all groups in an area such that some groups of people could even see a decline in their economic standing that is hidden by aggregate measures of economic growth. When an impact (e.g. increased wellbeing), is difficult to quantify, the problem of assigning attribution is only amplified. The logframe, as Krause explains, "separates evidence of one specific project result from all other effects NGO work might be having" $(2014,89)$, not to mention the potential entanglement of other causes and effects in the larger context in which a project or programme takes place. Yet, by framing the relationship between inputs and outcomes/impacts in such a direct, linear fashion, the 3Es logframe performs VfM in a particular way, a process explored further in the next section.

\section{The performativity of VFM}

As noted above, VfM at DfID is both a means of guiding decision-making and a defence of decisions made by DfID against what one interviewee called "the Daily Mails of the world". Thus VfM performs value firstly in the more literal sense of the word, as a demonstration of worth to justify spending decisions and defend against would-be critics. VfM can also be said to perform value in the more theoretical sense of being performative (as laid out in Chapters 1 and 2 this volume; see also, e.g. Callon 1998; MacKenzie 2003; MacKenzie et al. 2007; Mitchell 2002) i.e. as in fact effecting the reality it claims to describe (e.g. Muniesa 2014). VfM does not simply describe the relative value of different development projects and programmes, it shapes and enacts what counts as a valuable development project or programme in the first place. The remainder of this section expands on the notion of performativity as it relates to VfM.

Importantly, to say that something is performative - that it brings about the reality it claims to describe - does not necessarily entail a corresponding assumption that reality will straightforwardly and completely align with representations of itself (Fourcade 2011; Muniesa and Linhardt 2011). In the case of VfM, Krause's argument about logframes in general is apt: "Management tools like the logframe do not determine what people do, but they shape it: they shape what people get to see and know about the world, and people's ideas about what the task before them is" $(2014,76)$. VfM, with its requirements to quantify development outcomes and set them in a linear relationship to costed inputs using the $3 \mathrm{Es}$ logframe, shapes what desk officers, policy-makers and others see and know about development projects - what gets counted and what gets excluded from the frame of reference. It consequently shapes ideas about what types of results matter (i.e. ones that can be quantified) and how projects and programmes should be conceptualised - as involving a linear relationship between inputs and results or outcomes. Critically, by setting these parameters, VfM performs itself as a ratio of costed inputs to quantified (and if possible monetised) outcomes. Value that falls outside of this formulation - that is not quantifiable or cannot be set into a neatly linear relationship - is left out of the performance. 
Performativity, it should be noted, is not a one-off achievement but a matter of ongoing (re)iterations (Butler 2010, 149). Successive iterations of VfM assessment, within DfID as well as a wide range of donors, strengthen its ability to perform its constricted version of value, as more donors and contractors (e.g., NGOs) learn to shape their projects and programmes to deliver VfM as a ratio of costed inputs to outcomes. However in a broader sense, VfM as a set of practices can also be understood as a performative iteration of development value - as the quantified value of individual projects and programmes within the larger performativity of development economics and aid accountability. As one interviewee explained:

"One thing about all this VfM everyone talks about is that there's nothing new about it. It's what [development] economists have been doing for many decades: it's basically costeffectiveness analysis, cost efficiency, cost-effectiveness, and cost-benefit analysis. It's those things that used to be standard in project appraisals...the difference is that it has to be more explicit." (Interview 04/07/15)

In this quote, the interviewee - a freelance development consultant who had worked with DfID, the World Bank and other aid agencies for several decades - states that "there's nothing new" about value for money, likening it to previous modes of assessing the value of aid at the level of individual projects and programmes. Indeed it is true that VfM did not introduce economic accounting methods to international aid at the level of the individual project, a trend associated with the larger aid effectiveness, aid accountability and the new public management agenda of the 1990s. At the same time, VfM reinforces earlier iterations of development value as a linear economic relationship between quantified inputs and outcomes; it makes the parameters of development value both narrower and 'more explicit', bringing them to the front and centre of decision-making. Making things explicit, however, as Muniesa and Lindhardt (2011) point out, can bring new questions to the fore and open up new, previously hidden grey areas. This discussion on calculating VfM has showed how in the process of reinforcing the need to use certain types of (quantitative) evidence, VfM opens up spaces for negotiation, judgement and even 'gut feelings'. These openings however, should not be overstated. Negotiation and judgement are allowed, with restrictions, and the push to quantify is always present. The 3 Es logframe further constrains possibilities by forcing projects and programmes to figure a simplified linear relationship between costed inputs and quantified outcomes and impact. Values that cannot be quantified and thereby fitted into a clear linear relationship to inputs are framed out of the VfM equation, meaning they don't count in decision-making about what to fund and where. Accordingly, projects and programmes trying to 'sell' themselves to donors in the quasi-market described above will increasingly focus on projects that deliver narrowly defined VfM over other types of potential value. 


\section{Conclusion}

Marcus Leroy, a veteran of the international aid community, has written critically about VfM, arguing that:

“As much as utilitarianism, 'value for money' is fundamentally consequentialist. That means acts, in this case activities of an aid donor, are judged by their results, not by any preset ethic rules. Indeed, the 'value for money' approach is inspired by the idea that we can get rid of the political or moral dimension of the issues involved. It wants to translate every objective into a 'deliverable', a rational objective that has nothing to do with ideology." (2011, no page).

Of course VfM, and the aid effectiveness agenda of which it is a part, originated in the effort to make aid fairer, more accountable and, of course, more effective for its beneficiaries as well as for donors. Indeed, replacing ideology with rational decision-making in development aid seemed a laudable idea in the wake of the excesses of the cold war. It would be easy to say, as Leroy implies, that the limitations of VfM are evidence that the pendulum has swung too far in the direction of rationality, creating an 'iron cage' for development (cf. Weber 1958). This chapter has presented a more nuanced critique of VfM, demonstrating that it is not necessarily rational. After all, it is not rational to assume all development outcomes that matter to beneficiaries and donors can be clearly quantified and related to costed inputs! Moreover, it is not at all clear, as Leroy suggests, that DfID or the consultants and contractors it works with believes VfM will dispense with the political or moral dimensions of decisionmaking in the allocation and use of development aid. Gut feelings and expert judgement are undeniably part and parcel of the calculations. Rather, this chapter has shown that VfM acts as a tool for performing rationality. VfM performs rational decision-making as a justification for continued spending on international aid at a time of domestic austerity; and, more ominously, it performatively shapes what counts as development value by constraining the possibilities for measuring and framing that value to fit its conception of rationality. Instead of swinging the pendulum back to ideology, then, we should start thinking about opening up the category of what counts as 'rational'. We might replace the limited and limiting practices that currently constitute VfM and aid effectiveness with ones that embrace political, moral, and contextual considerations. 


\section{References}

Allen T. and A. Thomas eds. (2000) Poverty and development OUP, Oxford

Boin C. (2010) "Cutting waste at DfID has only just begun" The Telegraph

http://www.telegraph.co.uk/news/politics/conservative/7735786/Cutting-waste-at-DFID-hasonly-just-begun.html Accessed 24 July 2017

Bond (2011) "Value for money: what it means for UK NGOs: background paper" Bond, London https://www.bond.org.uk/data/files/Value for_money_-

what_it_means_for_NGOs_Jan_2012.pdf Accessed 24 July 2017

Butler, J. (2010) “Performative agency." Journal of Cultural Economy 3 147-61

Çalışkan K. and Callon M. (2010) "Economization part 2: a research programme for the study of markets. Economy and Society 39 1-32

Callon M. ed. (1998) The laws of the markets. Blackwell Publishers/Sociological Review, Oxford; Malden, MA

Cochoy F. (2008) "Calculation, qualculation, calqulation: shopping cart arithmetic, equipped cognition and the clustered consumer" Marketing Theory 815-44

Davis T. W. D. (2012) ACFID and 'Value for money' Discussion paper prepared for ACFID. Canberra: ACFID https://acfid.asn.au/sites/site.acfid/files/resource_document/ACFID-Valuefor-Money-Discussion-Paper.pdf Accessed 23 August 2017

Davis, K. E., B. Kingsbury, and S. E. Merry (2010) "Indicators as a technology of global governance" Law \& Society Review 46 71-104

DfID (2011) DfID's Approach to value for money (VfM). DfID, London http://mande.co.uk/blog/wp-content/uploads/2011/08/pub 031035.pdf Accessed 23 August 2017

Dixon L. (2010) "DfID accused of wasting money on taxis and offices" The Times http://www.thetimes.co.uk/tto/news/politics/article2785004.ece Accessed 24 July 2017

Fourcade M. (2011) "Cents and sensibility: economic valuation and the nature of "nature"'. American Journal of Sociology 116 1721-77

Fredriksen A. (2012) Making humanitarian spaces global: coordinating crisis response through the cluster approach. PhD Dissertation, Department of Sociology, Columbia University, New York

Hansen H. K. and Porter T. (2012) "What do numbers do in transnational governance?" International Political Sociology 6 409-426

ICAI (2011) ICAI's approach to effectiveness and value for money (No. 1) Independent Commission for Aid Impact, London https://www.bond.org.uk/data/files/ICAIs-Approach-toEffectiveness-and-VFM.pdf Accessed 23 August 2017 
Jackson P. (2012) Value for money and international development: deconstructing myths to promote a more constructive discussion. OECD Development Co-operation Directorate. http://www.oecd.org/development/effectiveness/49652541.pdf Accessed 23 August 2017

Krause M. (2014) The good project: the field of humanitarian relief NGOs and the fragmentation of reason. Chicago University Press, Chicago

Leroy M. (2011) “"Value for money' or 'results obsession disorder'?” The Broker http://www.thebrokeronline.eu/Blogs/Busan-High-Level-Forum/Value-for-money-orResults-Obsession-Disorder Accessed 24 July 2017

MacKenzie, D. (2003) An engine, not a camera: how financial models shape markets. MIT Press, Cambridge, Mass.

MacKenzie D., Muniesa F., Siu L.(2007) Do economists make markets? On the performativity of economics. Princeton University Press, Princeton

Merry, S. E. (2011) "Measuring the world: indicators, human rights, and global governance" Current Anthropology 52 S83-S95

Mitchell T. (2002) Rule of experts: Egypt, techno-politics, modernity. University of California Press, Berkeley.

Mosse, D. ed. (2011) Adventures in Aidland: the anthropology of professionals in international development. Berghahn Books, New York.

Mosse D. (2004) "Is good policy unimplementable? Reflections on the ethnography of aid policy and practice." Development and Change 35 639-71.

Muniesa F. and Linhardt D. (2011) "Trials of explicitness in the implementation of public management reform" Critical Perspectives on Accounting 22 550-566

Muniesa F. (2014) The provoked economy economic reality and the performative turn. Routledge, London.

OECD (2017) Paris declaration and Accra agenda for action.

http://www.oecd.org/dac/effectiveness/parisdeclarationandaccraagendaforaction.htm Accessed 24 July 2017

Poovey M. (1998) History of the modern fact: problems of knowledge in the sciences of wealth and society Chicago University Press, Chicago

Porter T. (1995) Trust in numbers: the pursuit of objectivity in science and public life Princeton University Press, Princeton

Rist G. (2003): The history of development: from Western origins to global faith, Zed Books, London 
Scott Z., McLoughlin C. and Marquette H. (2012) "Combining value for money with increased aid to fragile states: welcome partnership or clash of agendas?” Crime Law Soc Change, 58 509-519

TNS UK (2010) Public attitudes towards development. TNS Report prepared for COI on behalf of the Department for International Development. TNS UK, London

https://www.gov.uk/government/uploads/system/uploads/attachment_data/file/67684/publicattitudes-april10.pdf Accessed 23 August 2017

Vardakoulias O. (2013) New economics for: value for money in international development NEF consulting, London

Weber M. (1958) The Protestant ethic and the spirit of capitalism. Trans. Parsons T. Charles Scribner's Sons, New York

\section{Endnotes}

\footnotetext{
${ }^{1}$ Interview, London, 04/07/15

${ }^{2}$ For detailed histories of international development aid see, for example, Allen and Thomas (2000); Rist (2003)
} 